\title{
Evaluation of Architectural Characteristics for Conservation Decisions of Değirmendağı, İzmir, Turkey
}

\author{
KAPLAN Çağlayan Deniz ${ }^{1, a}$, MURTEZAOĞLU Fulya ${ }^{2, b}$, AKBULUT Özge ${ }^{3, c}$ \\ and İPEKOĞLU Başak ${ }^{4, d}$ \\ 1,2,4 Department of Architectural Restoration, Faculty of Architecture, İzmir Institute of Technology, \\ İzmir, Turkey \\ ${ }^{3}$ Metropolitan İzmir Municipality, İzmir, Turkey \\ acaglayankaplan@iyte.edu.tr, bfulyamurtezaoglu@iyte.edu.tr, 'ozge_akbulut@yahoo.com, \\ 'basakipekoglu@iyte.edu.tr
}

\begin{abstract}
Historical settlements, which are integral parts of the cultural heritage, should be documented and evaluated with their local characteristics. The aim of this study is to document, analyze and evaluate the architectural, environmental and social characteristics of an urban settlement called Değirmendağ 1 District, which has a historical background beginning with the Roman period to the present, in the center of metropolitan city of İzmir, on the Aegean coast of Turkey. The settlement is one of the earliest that was planned by local administration in İzmir and contributes to the İzmir silhouette with its location on a steep hillside in the township of Konak.

Documentation methods used are sketches, photography and architectural and social questionnaires. Inventory cards were prepared to collect architectural characteristics of each building and the social questionnaires were comprised of socio-economic characteristics of the settlers. Data gathered at the site was analyzed and evaluated to develop a conservation approach, including historical review of the ancient era.

Since the area is easily accessible and close to city center, the area becomes attractive. It has the advantage of the vista based on its inclined topography and grid-planned scheme. Değirmendağ1 District is a special area requiring special conservation within the city of İzmir. However, historical pattern has changed through the years because of changing lifestyle. The area, which is one of the most important and valuable districts in İzmir considering its history, location, and architectural characteristics should be integrated with the city and citizens. This study documents the present potentials and values of the area and forms a basis to prepare conservation approaches.
\end{abstract}

Keywords: Historical urban settlement, historic environment, documentation, analysis, conservation.

\section{Introduction}

The Değirmendağ 1 District is located on a hill in the township of Konak in the city of İzmir and is approximately 74 meters above sea level. The district warrants detailed analysis toward a conservation plan that recognizes its distinct history and character.

Besides the importance of its location, the district has always contributed to the urban silhouette of İzmir. The silhouette visible throughout the city has begun, in the last decades, to lose its historical identity extending to antique periods and its housing pattern going back to the $19^{\text {th }}$ century (Kaplan et al. 2006, Akbulut 2008). The objective of this study is developing specific conservational proposals by evaluating the specific problems presented by the distinctive characteristics of Değirmendağ 1 District as well as to inspire and improve the district in the economic, socio-cultural, and physical contexts. This study involved a dual methodology including archival and literature research and empirical fieldwork. The methods used to document the site are sketches, photographic documentation, and architectural / social questionnaires. Inventory cards were prepared and all the architectural characteristics of each building were collected on these cards. Social and economic 
patterns of the district were determined by social surveys for residents, and exterior and interior inventory cards for residential buildings. Then, all the data gathered at the site were analyzed and evaluated to support a possible conservation approach.

\section{Historical Background}

The history of the site reaches to ancient times. City maps dated to the $19^{\text {th }}$ century indicate that there was a Roman temple at Değirmendağı District. The site is located between two important gates (Ephesus Gate and Northwest Gate of Smyrna) according to these maps (Naumann and Kantar 1943). (Fig. 1). In engravings dating to the $18^{\text {th }}$ and the $19^{\text {th }}$ centuries, one can observe that Değirmendağ was not yet opened up for settlement. As seen in Fig. 2, it accommodated a couple of windmills upon the hill, and cemeteries on the lower slopes.

In the second half of the $19^{\text {th }}$ century, the Ottoman Empire was confronted with serious immigration problems stimulated by wars, Crimean War (1854), the Ottoman-Russian War (1877-1878), and the Ottoman-Greek War (1897), at almost all borders of the state. As a result of the treaties, accepted after these wars, over large refugee groups immigrated to Anatolia. This situation created serious resettlement problems. Ottoman Empire resettled some of the Tatarian and Rumelian refugees in Değirmendağı District (Baykara 1974, Serçe 1998).

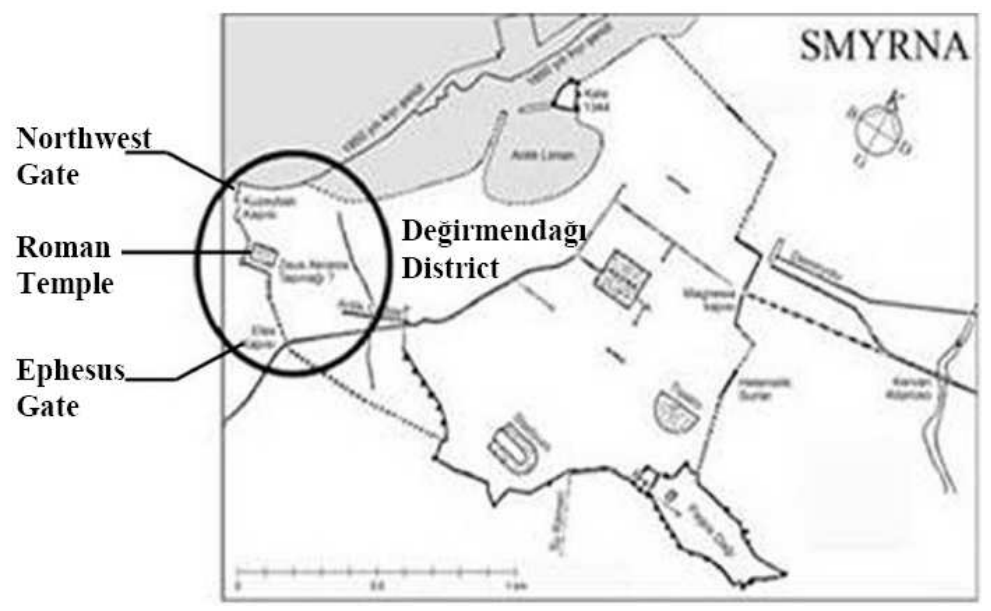

Figure 1: Plan of İmir in the Roman Period (Source: Naumann and Kantar 1943)

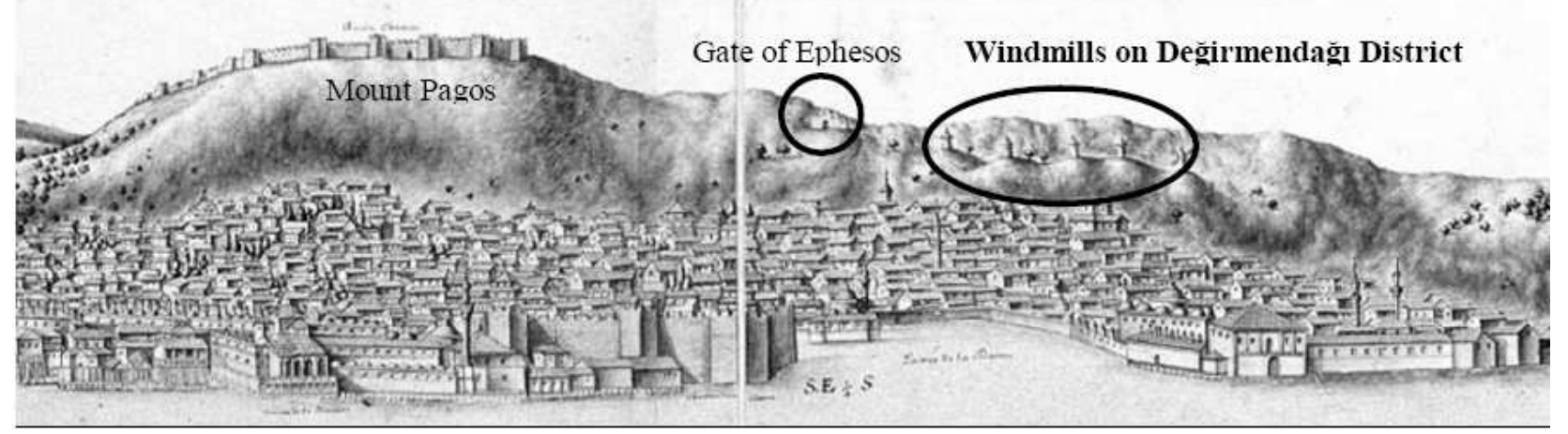

Figure 2: Izmir engraving, 1686 Combes (Source: National Library of France)

\section{Architectural Characteristics}

The common style of Ottoman urban space was organic pattern, wooden architecture and narrow streets that were the main reason for fires. Ottoman administration reconsidered a series of regulations that were controlled by local administration system to solve this problem. According to these Building Regulations dated 1882, wooden construction material was replaced with stone and brick. As a result 
of new regulations, width of streets and height of buildings were standardized, new construction materials were used and a grid system was applied in the new settlements (Denel 1982). All these regulations affected the Değirmendağ District as being part of the refugee settlements and a grid system was organized on a steep hillside area in Değirmendağı District (Temizsoy 2002).

Observed in general terms today, the survey area displays buildings with $19^{\text {th }}$ century architectural characteristics such as one or two-storey combined construction system buildings; vertically rectangular windows with casings of cut stone and iron shutters; iron consoles under cumbas, floor mouldings and eave cornices. Değirmendağı District has been regarded as an archeological site and historical settlement, and is included in the urban + third degree archaeological site in 2002.

Taking the density of the historical and registered buildings and the degree of alterations into consideration, Değirmendağı District is divided for the purposes of this study into three special zones, designated S1, S2, and S3 (Fig. 3). The buildings within the boundaries of the survey area have been examined in four separate groups as shown in Table 1.

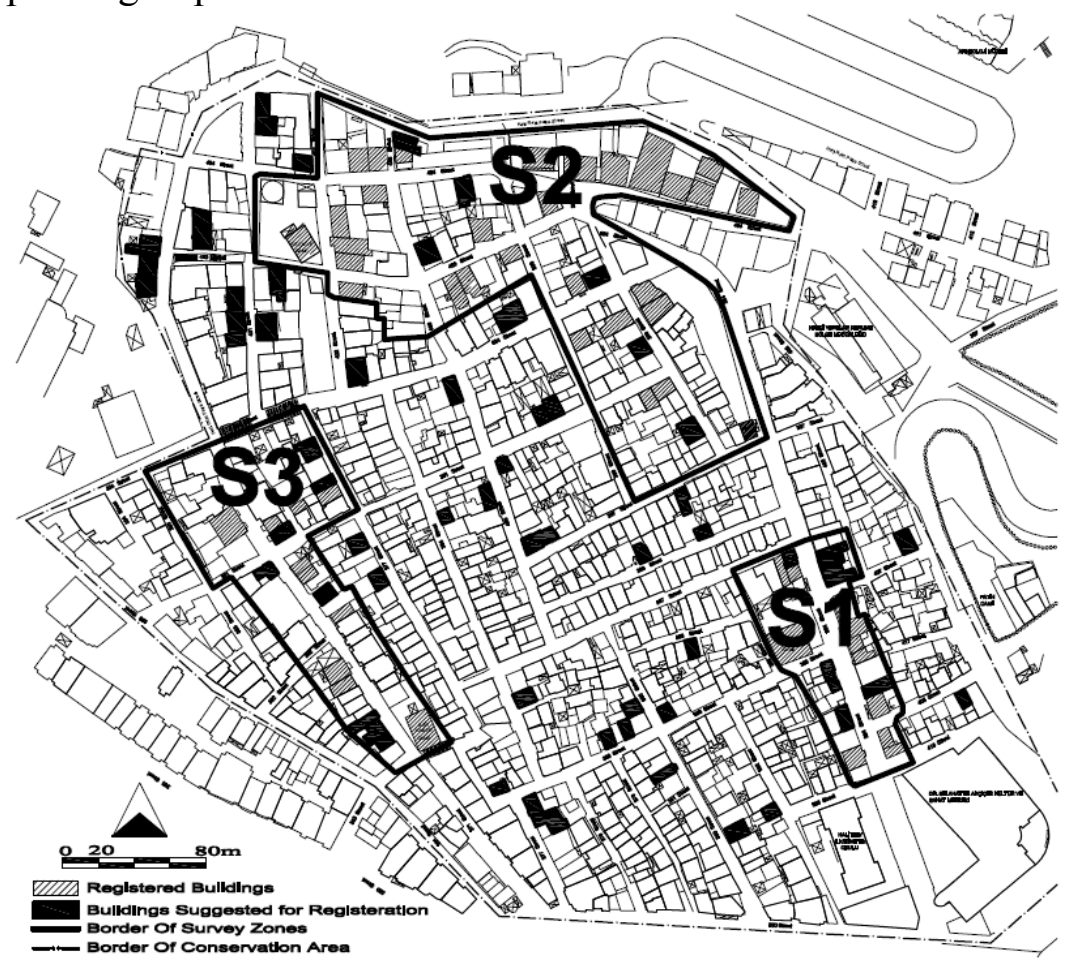

Figure 3: Three special zones (S1, S2 and S3) in Değirmendă̆ District

Table 1: Architectural Characteristics

\begin{tabular}{|c|c|c|c|c|c|}
\hline \multirow[b]{2}{*}{ Zones } & \multirow[b]{2}{*}{$\begin{array}{l}\text { Number of } \\
\text { Buildings }\end{array}$} & \multicolumn{4}{|c|}{ Groups Showing Architectural Characteristics } \\
\hline & & $\begin{array}{l}\text { Buildings displaying all } \\
\text { characteristics of } \\
\text { nineteenth century } \\
\text { residential architecture }\end{array}$ & $\begin{array}{l}\text { Buildings displaying only } \\
\text { partially characteristics of } \\
\text { the nineteenth-century } \\
\text { residential architecture }\end{array}$ & $\begin{array}{l}\text { Buildings } \\
\text { harmonious } \\
\text { with the } \\
\text { environment }\end{array}$ & $\begin{array}{l}\text { Buildings } \\
\text { inharmonious } \\
\text { with the } \\
\text { environment }\end{array}$ \\
\hline S1 & 31 & 9 & 18 & 4 & 0 \\
\hline $\mathrm{S} 2$ & 105 & 28 & 27 & 50 & 0 \\
\hline S3 & 44 & 14 & 21 & 7 & 2 \\
\hline TOTAL & 180 & 51 & 66 & 64 & 2 \\
\hline
\end{tabular}

The buildings which are most inharmonious with the environment are apartment buildings. They are generally 5 or 6-storey apartment buildings but in inner areas, there are not many buildings which are inharmonious with the environment in terms of number of storey.

There are extant 57 registered buildings in Değirmendağ 1 District. S1, S2 and S3 zones have 11, 33 and 11 registered buildings respectively and 2 registered buildings standing out of the boundaries of specific special zones. The 54 buildings to be proposed for registration were determined. There are 9 , 
6 and 8 buildings proposed for registration in the zones of S1, S2 and S3 respectively and 31 buildings were determined to be proposed for registration outside of these borders. Both groups are included in the urban +3 rd degree archaeological site.

Land Use It has been observed in the district that buildings are generally located next to each other on narrow plots in direct connection with the street. Most buildings have small gardens behind the structure. Additional buildings are generally in the form of outhouses built in the rear garden. Although Değirmendağı District has an inclined topography, streets have been deployed in grid system. Plots too, are in the form of a rectangular and organized in accordance with grid planning principles.

Building Functions The functions of buildings located within the boundaries of the district vary as residences, educational facilities, religious facilities and cultural facilities. In Değirmendağı District, there are 3 mosques, 2 schools, and one culture center. The remaining buildings are used as houses.

Number of Storeys In the survey area, the $80 \%$ of the buildings have one or two storeys. There are 4,5 , and 6-storey buildings along the boundaries of the survey area. It is clearly seen that the buildings with one or two storeys are common outside the special zones. The registered buildings generally have basement floors and penthouses are common in the relatively new buildings

Plan and Facade Types The plan types examined in Değirmendağ Thus, the classification has been made on the basis of first floor plans. The plan typologies of the buildings are generally organized with a hall on one side or in the middle. When the hall is positioned in the middle of the plan, it is used as a distribution space where all room doors lead. When the hall is located on the side, it is used only as a transition area. In two-storey buildings, the ground floor functions as a common area while the rooms on the upper floor are used as bedrooms. In some two-storey buildings, a cumba (projection extending from an upper floor of a house) is observed in the rooms on the upper floor. On the other hand, in some of the buildings, the cumbas have been eliminated or turned into a balcony.

The facade typologies are classified in terms of the position and the existence of a cumba, the position of the door and the number of storeys. The buildings with a cumba are divided into two categories as having the cumba and the entrance on the same axis and having the cumba and the entrance on different axes (Fig 4).

The houses contribute to street silhouettes with their facades including exterior architectural elements as entrance doors, windows, casings, cumba, balconies, shutters, iron railings, cornices and eaves. The mentioned exterior architectural elements express the aesthetical characteristics of the era that they were built (Fig. 5).
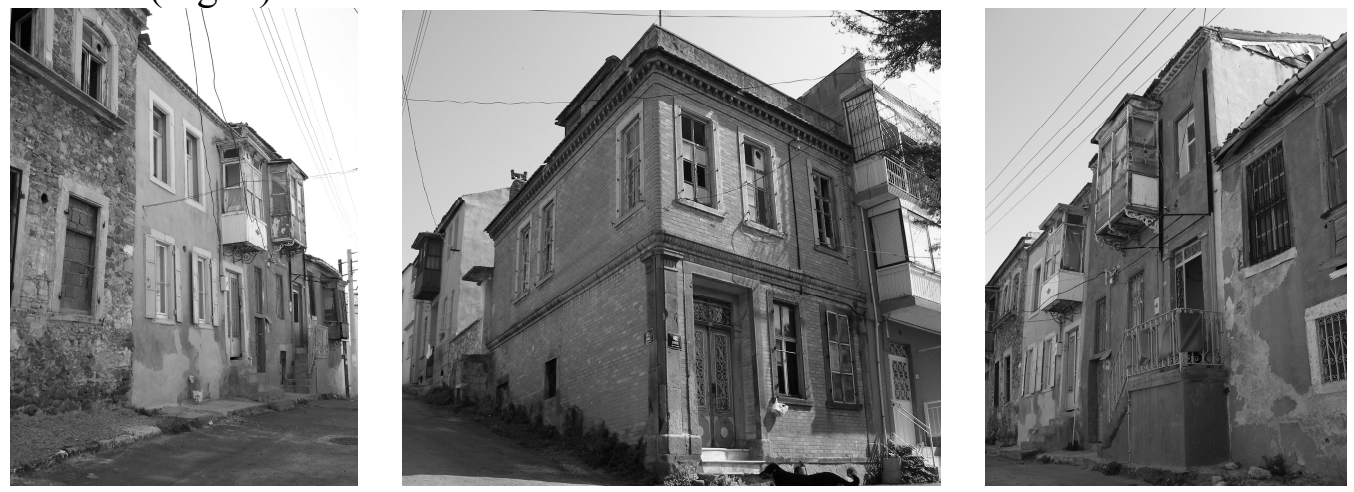

Figure 4: Façade Types 


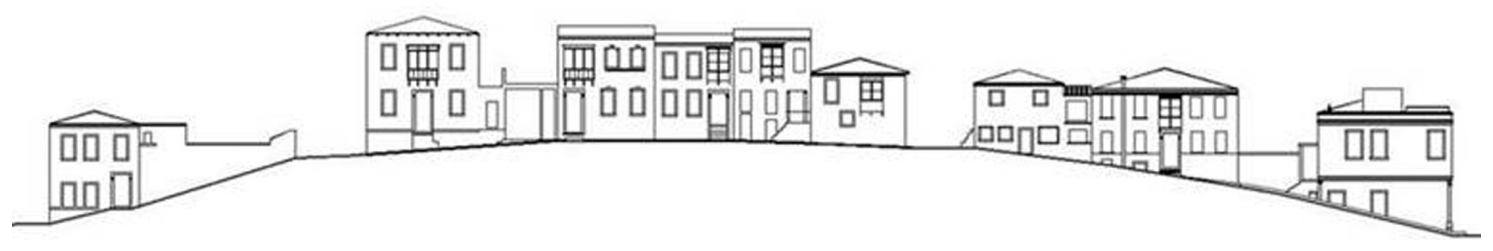

Figure 5: 403th Street Silhouette

Construction Technique The buildings in the survey area were studied in three groups in terms of their construction techniques, which consisted of a combined construction system (timber skeleton system at the interior and masonry system at the exterior are constructed as connected and juxtaposed), the solid masonry system, and the reinforced skeleton system. The buildings which are built in the masonry system are common in the area. The registered and historical houses are built in the combined construction system. The reinforced skeleton system is seen in new buildings.

Structural Condition and Alterations When the buildings in the survey area were examined from the outside, their structural condition was seen to be generally mediocre. The types of alterations in the survey area were studied under three main types as rebuilt buildings, horizontal division and additional elements to the existing buildings. Moreover, alterations such as the conversion of cumbas into balconies or elimination of cumbas, and alterations in materials were also observed. In addition, alterations in dimensions and materials of facade elements such as doors and windows were also determined.

\section{Socio-Economic Characteristics}

The survey to determine the socio-economic characteristics in Değirmendağ District was conducted in 36 houses with 9 families from the S1 zone, while 20 families from the S2 zone and 7 families from the S3 zone were interviewed. The reason for this unbalanced distribution of surveyed families owes to residents' willingness to participate in the survey.

Only 20 residences are privately owned and the rest of the residents pay rent. The origins of the families living within the survey area are mostly from outside İzmir or from Konak.

Where people with higher education among other family members living in the houses within a survey area are concerned, 24 people in the district are determined graduated from primary school while 16 people graduated from higher schools. There is 1 illiterate person and 3 people from universities. The profession of the family head was taken as the norm profession for the household. According to the survey results, there are 11 retired people, 4 government employees, 15 workers and 1 self employed. Survey results indicated that workers are generally living on the inner parts, remote from main arteries, on account of lower rent and its closeness to the city center. On the other hand, it was determined that the number of persons lacking literacy is very low. This condition may create an advantage for organized conservation work in the district.

\section{Evaluation of Problems and Potentials}

In an environmental scale, the district is faced with various problems, such as lack of proper care, dereliction and change in users, and has turned into a slum area in the middle of İzmir city center. The workers coming from other cities choose the district as a housing area because of rather low rent rates and its closeness to the city center.

New multi-storey buildings are being built along the boundaries of the survey area constituting a threat for the inner segments of the district. As a matter of fact, it is determined that old houses are being destroyed and new buildings are being built.

The problems concerning transportation are narrow streets, lack of adequate parking and lack of public transportation through the inner parts. There are no parks or green areas for the children. 
As a potential, since the area is easily accessible and it is so close to the city center, the area becomes attractive. It has the advantage of the vista based on its inclined topography and grid planned scheme. In a regional scale, Değirmendağ 1 District is a special area requiring special conservation in the city of İzmir. There are 57 registered buildings and 54 buildings to be proposed for registration observed in Değirmendağı District which is included into the urban +3 rd degree archaeological site.

The S1, S2, S3 zones can be improved by means of appropriate conservation decisions.

Although the listed buildings in the site are generally in structurally sound condition, some of the exterior architectural elements were altered using contemporary building materials. This misuse of the buildings causes damage on the city silhouette. In some of the examples, the original plan scheme of the building cannot be traced. It is very easy to make alterations to the original architectural elements now because there is no control by governmental authorities.

\section{Conservation Proposals}

Değirmendağı District is one of the most important and valuable districts in İzmir considering its history, location and architectural characteristics. This area should be integrated with the city and its citizens. An equitable and livable heritage conservation perspective is urgently imperative.

The residential-use in the area will be continued by restoration and rehabilitation. Since the S1, S2, and S3 zones were determined as the prestige areas of Değirmendağ District, they will have priority in implementation. When construction is required on the lots, foundations of the Roman Temple shall be explored under the supervision of a technical team provided by the Archeological Museum of İzmir. Some of the registered buildings are to be used for social and cultural purposes as public education centers and local workshops. Since the streets are too narrow, utilization of one-way streets and increase in number of parking lots are proposed. Additional green areas and play grounds will be arranged. The electricity cables and telephone lines creating an unaesthetic view will be taken under ground. The streets, paved asphalt, will be repaved with parquet stones.

The objective of the development project for Değirmendağı District by means of evaluating conservation problems of the district was to preserve and to improve local characteristics while inspiring revitalization in the district in terms of its economic, socio-cultural, and physical aspects. The organizational model, intended for the conservation of this area, was generated by means of the coordination of local administrative bodies, city administrative bodies, local residents, and nongovernmental organizations.

\section{References}

[1] Akbulut, Ö (2008) "Evaluation of Conservation Problems of Değirmendağ District in İzmir." Unpublished MS Thesis, Supervisor: B. İpekoğlu, İzmir Institute of Technology, İzmir.

[2] Baykara, T (1974) “İzmir Şehri ve Tarihi.” İzmir: Ege Üniversitesi Arkeoloji Enstitüsü Yayınları.

[3] Denel, S (1982) “Batılılaşma Sürecinde İstanbul'da Tasarım ve Dış Mekanlardaki Değişim ve Nedenleri." Ankara: ODTÜ Mimarlık Fakültesi Yayınları.

[4] Kaplan, Ç D, Murtezaoğlu, F, and Sayg1, G (2006) "Survey, Analysis and Evaluation of Değirmendağı District, in the town of Konak in İzmir." Unpublished Report, Course RES 511 Preservation and Development Methods of Historic Environment, Supervisor: B. İpekoğlu, Graduate Program of Architectural Restoration, İzmir Institute of Technology, İzmir.

[5] Naumann, R, and Kantar, S (1943). "İzmir'de Roma Devrine Ait İyon Agorasında Yapılan Hafriyat Hakkında İkinci İhzari Rapor." (Turkish), in Belleten, paper 7.25, 231-225.

[6] Serçe, E (1998). “Tanzimat'tan Cumhuriyet'e İzmir'de Belediye (1868-1945).” İzmir: Dokuz Eylül Yayınları.

[7] Temizsoy, A (2002). "Resettlement of Balkan Refugees in İzmir during the Late Ottoman Period: A Survey on the Urban and Architectural Properties of the Planned District of Değirmendağı." Unpublished Master Thesis, Middle East Technical Univ., Ankara, Turkey. 